\title{
Juvenile Delinquency in Uttarakhand Part II: The Victim of a Violant Crime
}

\author{
Gaurav S. Khetwal ${ }^{1} *{\text { Chitra } \text { Khetwal }^{2} \text { and Kalpana Khetwal }}^{2}$ \\ 1. Department of Sociology, H.N.B.University Srinagar Garhwal, Uttarakhand, India \\ 2. Department of Sociology, Kumaon University Nainital, Uttarakhand, India. \\ 3, Department of English, Kumaon University Nainital ,Uttarakhand, India. \\ Email:gauravkhetwall@gmail.com,*For correspondence
}

\begin{abstract}
The observation homes, in Uttarakhand have a number of juvenile delinquents arrested under different types of crimes. A high school student aged 15 yrs belonging to a very simple family committed a violant crime but provocated by his own mother. In the day time his mother had a quarrel with her neighbour regarding a passage. She was so annoyed with the neighbour that when her son came from school she narrated the day's heated event and provoked her son to chop neighbour's head. The young sentimental child became so angered with revenge that without any pause brought a sharp weapon from inside the kitchen and repeatedly attacked the lady till she fell down and took her last breath. The news spread like a fire in the town. Police was called who arrested both mother and son to lock up. Everyone knew the boy was innocent but he committed a felonious crime just by obeying his mother.
\end{abstract}

KEYWORDS: Violant crime, feloney,observation home. juvenile delinquency

\section{INTRODUCTION}

Petty crimes in general and heinous crimes in particular are being committed regularly by children not only in India but world. Crimes such as theft, burglary snatching which are not to serious in nature or crimes such as robbery, dacoity, murder and rape etc which are relatively serious are on the rise in whole of the country. And the unfortunate thing is that all types of these crimes (Sellin 1937; Franz and Status 1956, Piquero, Alex R., J. David Hawkins, and Lila Kazemian,2012) are also being committed by children below the age of 18yrs. (Farrington, David P 1986) The recent inhuman brutal Nirbhaya gang rape of a young girl in Delhi on $16^{\text {th }} 2012$ shocked the collective conscience of the nation. It was most shocking to know that out of the six accused the most barbaric one was a juvenile who was likely to complete $18 \mathrm{yrs}$ of age at the time of the heinous crime. Considering the case as rarest of the rare Delhi high court awarded capital punishment on to five of them on Dec $13^{\text {th }} 2013$ while the juvenile was sent to an observation home. One accused committed suicide inside the jail while the death penalty of the four accused was upheld by supreme court on May $5^{\text {th }}$, 2017 (Times of India 2017)' The most barbaric juvenile delinquent was scot free after three yrs in 2015. After this rape case there was a nation wide debate to whether the age limit should be below 18yrs of age or 1516yrs.(Hindustan times Aug 14,2014 ),

No one is born criminal, circumstances make him so. Socio-cultural environment both inside and out side of home plays significant role in shaping one's life and overall personality of a juvenile. Children are considered the personal as well as greatest national assets. We as individuals, parents guardians and society as a whole have a duty that children should be allowed and provided opportunity in a healthy socio cultural environment so that they could become responsible citizens, physically fit, mentally alert and morally healthy. It is the duty of state as well as parents to provide equal opportunity for the development of all children during the period of their growth which would reduce inequality and ensure social justice. Children are expected to be obedient respectful and have virtues and good quality in them. However due to various reasons certain percentage of children do not follow settled social and legal dictum. Such children are most often than not get envolved in criminal behaviour which is known as juvenile delinquency or juvenile crime. Its a disturbing trend and society as a whole is anguished by such criminal acts by children. Legally speaking a juvenile can be defined as a child who has not attained a certain age at which he can be held liable for criminal acts. As per the juvenile justice ( care and protection) act 2000. A juvenile shall not be treated as an adult even if he/ she is involved in any criminal acts for the purpose of trial and punishment in the court of law. But After the Nirbhaya case in India govt has reconsidered the age of the juveniles in India and media has welcomed the government's decision to approve a bill to allow children over 16 to be tried as adults for crimes like rape and murder ( Hindustan times, 2014) 
Easy available of firearms, abusive parents, single parent child, nuclear family, family violance, child sexual abuse and role of media are normally the reasons for juvenile crimes. However, as far as India is concerned it is the poverty which make juveniles more inclined towards criminal activities. Poverty is considered the biggest causes which force a child to get involved in criminal acts but in the present case not poverty but mother's provocation resulted the heinous crime. The juveniles in conflict with law be kept in an "observation home" while children in need of care and protection need to be kept in "children home "during pendency of proceeding before the competent authority. A juvenile can be detained only for a maximum of 3 yrs irrespective of the gravity of offence committed by him and he will be remanded to "special home". The purpose of this new act was to rehabilitate the child and assimilate him /her in the main stream of the society.

Madan an innocent boy belonging to a remote village in Uttarakhand state fell victim of a violent crime under accidental criminality as has been discussed in this paper

\section{A CASE STUDY}

While studying the cases of the inmates of an observation home in Uttarakhand Madan ( name changed) a resident of a boarder village in Uttarakhand. revealed his storey as to why he was in the observation home. He belonged to a very simple family of Uttarakhand studying in the local high school. His father was serving in Indian army and mother a home maker. Like several others in the villages of Uttarakhand his father shifted his family in the near by town just for better education of his children. He left his ancestral residence and fertile agricultural land in the village and moved to the nearby town. In the beginning he lived in a rented house and later purchased a residential plot where he built his own house. It has become tradition in Uttarakhand hills that a person doing a small job govt or private leaves his village property ( residential house agricultural land etc) and prefers to settle in the neighbouring town. or city. As a result of this migration the houses in Uttarakhand villages have become deserted and fertile land barren. Such families once settled in cities hardly turn back.

While constructing the house his father covered all the land he purchased resulting which the route leading to the neighbour's house was shrunk. This resulted in a day to day rift in between the two families. Often there was a quarrel between two neighbouring ladies. The neighbour was also an army personal migrated from the neighbouring village His family also lived alone with two small kids while he was posted in the field. After the house construction was over Madan's father left home to resume his duty in in Arunchal Pradesh. Madan aged 15 and his younger sister aged 10yrs used to go to school in the morning and come back in the evening while mother living alone at home. This was the simple routine of this small family. One day when Madan and his sister were in the school there was a quarrel in between his mother and the neighbouring lady regarding the passage. There was heated exchange with abusive words .The ugly abusive quarrel turned violant when Madan's mother was physically hit by the neighbour and she got injured.

When Madan returned from school in the evening his mother narrated the day's event She provoked Madan for taking revenge and asked him to chop neighbour's head. Hearing this Madan could not control his anger and became so furious that without any pause he went inside the house brought a sharpened wood cutting weapon. Literally crying and challenging he hit hard the neighbour several times. The lady fell down and died on the spot. Since there was none to mediate Madan resulted the bone chilling crime in no time. This incident spread like fire and shocked the conscience of the town. Immediately police appeared on the spot, arrested Madan and his mother and put them behind bars. The anger was just like as heard in US ( Juliana Rose Pignataro 2017) when teenagers shot several of their school mates with a revolver. Had the mother not provoked her son they would not have to face police action and go jail."Adolescent and youth tend to make use of brute physical force or use of weapons readily obtained or which can be made from material at hand, the home-made gun the sharpened cane, the knife ordered through a mail order catalogue "Second category "The younger the offender the less he plans" (Ruthshonle 1962). The readily available weapon with Madan was a sharpened woodcutter He never had the plan to hit the neighbouring lady. Madan became the victim of violent criminality. Criminality as discussed by Sutherland and Cressey in the book "Principles of Criminology (Sutherland and Cressey 1955). "Such criminal momentarily behave criminally when provoked with an intense cries, is also provoked by external events, even though the actual nature of the reaction again depends upon the state of his ego and unconsciousness. The principal difference, therefore, between the chronic and the accidental criminal seems to be that in the first form the trigger to the criminal behaviour is intra pshychic whereas in the latter original stimulus arises in the environment." The momentary environment provoked Madan's anger which changed not only his fate but also his family. (Rolf Loeber and David 'eP. Farrington, New York: Prediction, and Prevention from Childhood, eds. Springer, 2011). "Principles of Criminology (Sutherland and Cressey 1955, Ruthshonle 1967) in his book "Juvenile Delinquency" 


\section{CONCLUSIONS}

It is very difficult whom to blame Mr Madan become a juvenile delinquent. His mother, who provoked him to commit the crime. or he himself for committing the heinous crime. The parents must take responsibility over their children up to the time when they would be in a position to stand on their own. This involves providing for their children's material needs and giving them moral guidance. Many parents forfeit their role and leave it on their children's wishes There must be a realisation that in adulthood, values come from the family, religious and education background. Therefore, parenthood (Anderson, Craig A. and Dona C.Anderson. Anderson, Craig A. and Dona C. Anderson. 1984..) should be taken more seriously which effects the life of their children.

\section{REFERENCES:}

[1] Anderson, Craig A. and Dona C. Anderson. 1984. "Ambient Temperature and Vio-lent Crime: Test of Linear and Curvilinear Hypotheses.' Journal of Personality and Social Psychology,46:91-97

[2] Carl McCurley and Howard N. Snyder 2004, Victims of Violent Juvenile Crime U.S Juvenile justice bulletin pp, 1-8

[3] Farrington, David P1986., "Age and Crime," in Crime and Justice: An Annual Review of Research, vol. 7, eds. Michael Tonry and Norval Morris, Chicago, Ill.: University of Chicago Press,: 189-250

[4] Gaurav S.Khetwal**, Urmila Rawat and Chitra Khetwal 2009.Juvenile delinquency in Uttarakhand Part I A victim of situational crime .Journal of Social Sciences, 21(1) 79-81 2009.

[5] Heleen J. Janssen, Frank M. Weerman, Veroni I. Eichelsheim 2016 ,Parenting as a Protective Factor against Criminogenic Settings? Interaction Effects between Three Aspects of Parenting and Unstructured Socializing in Disordered Areas Journal of Research in Crime and Delinquency;181-207.

[6] Hindustan times 2014,Aug 14, 2014

[7] Juliana Rose , Pignataro 2017, Teens Who Shot 14-Year-Old Over Snapchat To Be Tried As Adults International Business Times (IBT) May 12

[8] Piquero, Alex R., J. David Hawkins, and Lila Kazemian2012, "Criminal Career Patterns," in From Juvenile Delinquency to Adult Crime: Criminal Careers, Justice Policy, and Prevention, eds. Rolf Loeber and David P. Farrington, New York: Oxford University Press,: 14

[9] Ruthshonle Cavan 1970. Juvenile Delinquency. In: R D Knudten, Stephen Schafer (Eds.): A Reader: Offence Primarily Injurious to Others. New York: Randam, pp. 141-151A

[10] Rolf Loeber and David P. Farrington,2011, New York: Prediction, and Prevention from Childhood, eds. Springer, 137-152

[11] Rolf Loeber, Wim Slot Crime and justice 2007,Serious and Violent Juvenile Delinquency An Update vol 35, pp. 503-592

[12] Sutherland Edwin, Donald H, Cressey R 1955. Principalsof Criminology. 5th Edition, Chicago, Philadelphia,NewYork: J.B.Lippincott Company, Ch.11, pp. 189-218.

[13] Shafer Stephen, Knudten Richard D 1970. The Nature of Delinquency :Juvenile Delinquency An Introduction.Philadelphia New York: J.B. Lippincott Company ,Ch 14 pp. 220-230.

[14] Sellin Thorsten 1937. Culture, Conflict and Crime: Research Memorandum on Crime in Depression. New York: Randam House, pp. 10-35

[15] Times of India 2017, Delhi Edn May 6 ${ }^{\text {th }} 2017$ 